NBER WORKING PAPER SERIES

TAX CHANGES AND CAPITAL

ALLOCATION IN THE 1980S

Patric H. Hendershott

Working Paper No. 1911

NATIONAL BUREAU OF ECONOMIC RESEARCH

1050 Massachusetts Avenue

Cambridge, MA 02138

Apri1 1986

The research reported here is part of the NBER's research program Capital Formation. Any op in ions expressedgets and Taxation and and not those of the National Bureau of Econo those of the author 
NBER Working Paper \#1911

Apri 11986

\title{
Tax Changes and Capital Allocation in the 1980 s
}

\begin{abstract}
The paper begins with presentation of a methodology for computing rental costs of capital under any tax regime. Tax law over the 1980-84 period is specified and the provisions of the Treasury and Administration tax reform proposals and HR 3838 are described. A model is then constructed to allow calculation of the impact of changes in tax regimes and/or expected inflation on interest rates and the allocation of real capital. The model allocates a fixed private capital stock among various classes of nonresidential and residential capital, depending upon the rental costs for the capital components, the price elasticities of demand with respect to the rental costs, and the elasticities of homeownership with respect to the cost of owning versus renting. The interest rate adjusts in response to tax/inflation changes so as to maintain the aggregate demand for capital at this initial level. The model is employed to deduce the efficiency of the allocation of real capital under various tax regimes at different inflation rates.
\end{abstract}

Patric H. Hendershott Hagerty Hall The Ohio State University 1775 College Road

Columbus, Ohio 43210 
Tax Changes and Capital Allocation in the 1980s

Patric H. Hendershott

Three tax bills were enacted in the first half of the 1980s: the Economic Recovery Tax Act of 1981, the Tax Equity and Fiscal Responsibility Act of 1982, and the Deficit Reduction Act of 1984. Moreover, major tax reform proposals, most notably the November 1984 Treasury plan and the May 1985 Administration plan, have been advanced for implementation in the second half of this decade and the U.S. House of Representatives passed a reform bill in December 1985. The passed or proposed tax changes have altered or would significantly affect both the overall taxation of capital and taxation in different uses. As a result, changes in interest rates, homeownership, and

$\because \quad$ investment in various types of capital have or would probably be induced. The nature and extent of these changes are the subjects of this paper.

The method of analysis is the construction and manipulation of a relatively small simulation model. The principal features of the model are the dependencies of the demands for various types of capital on their gross (of depreciation) user costs of capital and of the user costs on tax parameters and interest rates. Special emphasis is placed on the housing sector where households at six different income levels make tenure and quantity-demanded decisions. Finally, the level of taxable interest rates is determined by equality between the total demand for capital and the existing capital stock.

The model is first used to simulate the 1981-82 tax changes. ${ }^{1}$ The implied effects of the tax legislation on interest rates, homeownership, and capital allocation are then compared with observed changes in the 1981-84 period. The model implications are at least roughly consistent with observed 
events. The model is then employed to simulate the impacts of the Treasury and Administration tax proposals and the House bill. The proposals are analyzed in a five percent inflation world; the inflation neutrality of current law and the reform proposals are compared; and efficiency losses due to misallocation of capital are computed for the various tax regimes.

I. Investment Hurdle Rates or User Costs

\section{General Considerations}

As is well known (Hall and Jorgenson, 1967), the decision to invest depends on whether the present value of the expected revenue from investment exceeds the supply price of capital, and on marginal investments the two will be equal. After allowance for taxation, the equilibrium condition for investment is

$\because$

$$
\rho=\frac{\left(x+d+\tau \pi^{\pi)(1-k-\tau z)}\right.}{1-\tau} .
$$

where $\tau$ is the business tax rate, $\rho$ is the gross marginal product of capital, $r$ is the real after-tax financing rate, d is the economic depreciation rate, $\tau_{\pi}$ is the concurrent equivalent tax rate on inflationary gains, $\pi$ is the expected inflation rate, and $k$ is the investment tax credit. ${ }^{2}$ In general, $z$ is the present value of the stream of tax depreciation allowances, TAXDEP $t^{\prime}$ obtained by discounting the stream of depreciation allowances by the required nominal after-tax financing rate; taking into account the reduction in depreciable basis if the investment tax credit is claimed:

$$
z=(1-\mathrm{k} / 2) \sum_{t=1[(1+r)(1+\pi)]^{t}}^{N} \frac{\operatorname{TAXDEP}_{t}}{.}
$$


where $\mathrm{N}$ is the depreciation period of the asset. The right side of equation (1) is the "investment hurdle rate" or rental user cost for a particular asset. The lower the user cost, the greater will be production of the asset, and the lower will be the productivity of the marginal investment $(0)$. In a "neutral" tax system, the net user and thus net marginal productivities $(\rho-d)$ would be the same for all equally-risky assets. This can be achieved in a variety of ways. For example, with $k=0, \tau=0$ and either $z=1$-- expensing -- or $\tau=0$, then $\rho-d=r$. If the $r^{\prime} s$ were equal for all assets, the tax system would be neutral across them. Alternatively, with $k=0, \tau_{\pi}=0$ and $z=d /(r+d)-$ tax depreciation equal to economic depreciation, then $\rho-d=r /(1-\tau)$. If the $r^{\prime} s$ and the $\tau^{\prime} s$ were the same for all assets, then the system would also be neutral. Because the $\tau$ 's are zero for owner-occupied housing, expensing for depreciable assets (and the nondeductibility of property taxes on owner-occupied housing) would lead to tax neutrality -- assuming equal r's -- but setting tax depreciation equal to economic depreciation would not. ${ }^{3}$

Assuming that firms use a fixed fraction of debt, $b$, for financing all investments, the real after-tax financing rate can be expressed as

$$
r=[b(1-\beta \tau) i+(1-b)(1-\gamma \tau) e-\pi] /(1+\pi),
$$

where $\beta$ and $\gamma$, respectively, are the portions of interest and equity returns that are deductible at the business level, and $e$ is the required nominal return to investors. (Currently $\beta=1$ and $\gamma=0$. ) Firms will choose the $b$ at which the marginal costs of debt and equity, including contracting and bankruptcy costs, are equal. (Because this marginal cost is unknown, average values of $i$ and $e$ are used in the calculation of $r_{\text {.) }}$ 
Portfolio equilibrium of investors requires that

$$
(1-\tau) e=(1-x) i+\delta .
$$

where $\tau_{e}$ is the rate at which equity returns are taxed at the personal level, $\mathrm{x}$ is the relevant tax rate for taxable interest (the lower of the personal tax rate and that implicit in tax-exempt yields), and $\delta$ is the risk premium required on equity investments. For all investments except owner-occupied housing of low and middle income households, $x$ is the tax rate implicit in tax-exempt yields $\mathrm{x}_{\mathrm{e}}$. Substituting (4) into (3), the real after-tax financing rate for capital other than owner-occupied housing is:

\[ x=\left[b(1-\beta \tau) i+(1-b)(1-\gamma \tau) \frac{\left(1-x_{e}\right) i+\delta}{1-\tau_{e}}-\pi\right] /(1+\pi) \cdot \quad \text { (3') } \]
If $\tau \gamma$ were equal to $\tau_{e}$ (which would be true if $\gamma=\tau_{e}=0$ ) and $x_{e}=\beta \tau, r$ would equal $[(1-\beta \tau) i-\pi+\delta(1-b)] /(1+\pi)$ for all assets. Further, if all interest expense were deductible at the same rate and all investments were equally risky, all r's would be equal.

For corporations, $\tau_{e}$ depends on the taxation of dividends and capital gains and the division of equity raised between new issues and retained earnings (Auerbach, 1979). More generally,

$$
\tau_{e}=n \tau_{d i v}+(1-n) \tau_{c g}{ }^{\prime}
$$

where $\mathrm{n}$ is the proportion of equity funds raised by new issues, and $\tau_{\mathrm{div}}$ and ' $c g$ ' respectively, are the effective tax rates on dividends and equity capital gains. In general, $\tau_{\mathrm{div}}=\tau_{i \mathrm{~m}} / 2$ and $\tau_{\mathrm{cg}}=(1 \text {-exclu })_{\tau_{\mathrm{m}}} / 4$, where $\tau_{i \mathrm{~m}}$ is the effective maximum tax rate on personal interest and exclu is the statutory 
capital gains exclusion. The divisions by 2 and 4 allow for tax deferral and avoidance activities. An $n$ of 0.1 is assumed; as a result, $t_{e}$ is relatively low $10.14_{\mathrm{T}}$ im under current law). For noncorporate businesses (including households investing in owner-occupied housing), te equals 0 .

Empirically, the tax rate implicit in tax-exempt yields varies with the maturity of the security. For short-term tax exempts, the ratio of prime grade tax-exempt to risk-free taxable yields has not deviated far from unity less the corporate tax rate or roughly 0.5. For ten-year bonds, which are more relevant for the long-term investments being analyzed, the ratio has been closer to 0.7 . The implicit tax rate of 0.3 , rather than the federal tax rate of 0.46 (the state and local tax rate is not relevant if corporations invest in their own jurisdictions), reflects a number of factors, but the most important is likely the tax saving from optimally trading bonds (e.g.. taking capital losses and deferring capital gains). ${ }^{4}$ This is especially important because high transactions costs virtually eliminate any gains from trading municipal bonds. The tax rate implicit in long-term tax-exempt yields is assumed to be given by:

$$
x_{e}=(\beta-0.3) \tau_{f}
$$

where ${ }_{f}$ is the federal corporate tax rate and the 0.3 measures the gains from optimal trading.

All interest expense is not deductible at the same rate, the clearest example being owner-occupied housing. Because this asset is held by households with a wide range of income subject to the full array of marginal personal tax rates, the tax rates at which interest is deductible (and at which equity the owner has in the house would have been taxed had the household rented) vary across households. ${ }^{5}$ More generally, the real after-tax financing rate for the jth household is 


$$
r_{j}=\left[b_{j}\left(1-\tau_{j}\right) i+\left(1-b_{j}\right)\left(1-x_{j}\right) i-\pi+\delta_{j}\right] /(1+\pi) .
$$

The tax rate applicable to own equity investment, $x_{j}$, is defined as the minimum of the tax rate paid on the last dollar of taxable interest earned, $B \tau_{j}$, or that implicit in tax-exempt yields, $x_{e}$.

For all investments other than real estate, $b=1 / 3$. For real estate investments other than owner-occupied housing, $b=2 / 3$. This assumption is consistent with available data on large-scale (over 50 unit) rental projects, which probably accounted for over two-thirds of the rental units constructed in the 1970s. ${ }^{6}$ The data in Table 1 indicate that ownership of these properties has shifted sharply from corporations to partnerships over the past two decades (the vast majority of additions to the stock have certainly been owned by partnerships), most of these properties have mortgages (97 percent of those owned by partnerships in 1980), and the initial loan-to-value ratio on the 81 percent of properties with a first mortgage at time of purchase is 87 percent. In 1970, the median loan-to-value ratio was 67 percent. The median was only 53 percent in early 1981, when mortgage rates were at historic highs and terms had been quite unfavorable for refinancing for three years. The two-thirds ratio is a reasonable approximation for a present-value, weighted average loan-tovalue ratio in normal times.

For owner-occupied housing, we vary $b_{j}$ depending on the relative attractiveness of debt and equity financing. More specifically,

$$
b_{j}= \begin{cases}0.667 & \text { if } x_{j}=\tau_{j} \\ 0.85 & \text { if } x_{j}<\tau_{j}\end{cases}
$$

By our definitions, $x_{j}$ cannot exceed $\tau_{j}$. While these ratios far exceed the 0.33 to 0.4 average economy-wide ratio observed for owner-occupied housing, the observed ratio is heavily influenced by older owning households who have repaid their mortgages and are relatively insensitive to housing rental costs 
The 1981 Tax Act also cut the maximum federal tax rates, from 0.48 to 0.46 for corporations and from 0.7 to 0.5 for households. We assume that the marginai noncorporate investor was in the 54 percent bracket in 1980 (at roughly the same real income level at which the 49 percent tax rate applied in 1985). The income tax rates in Table 3 presume a 0.06 state and local tax rate deductible at the federal level.

The personal tax rates on real corporate equity returns follow from equation (5) and the surrounding discussion, given a capital gains exclusion of 0.6 (0.0 under the Treasury plan, 0.5 under the Administration plan and 0.42 in the House bill). The tax rate implicit in tax-exempt yields follows from equation (6). Finally, the inflation tax, $\tau_{\pi}$, is $0.7 \tau$ on inventories because FIFO accounting is used for 70 percent of inventories and is effectively zero for other assets.

The Treasury plan attempted to neutralize the tax system for inflation by indexing everything. Only real capital gains, including those on inventories, would be taxed $\left(\tau_{\pi}=0\right)$; depreciation would be on a replacement, rather than historic, cost basis; and only the "real" part of interest expense would be taxed and could be deducted. ${ }^{10}$ The Treasury plan also attempted to tax all assets and business forms (except owner-occupied housing) equally. To this end, tax depreciation for each depreciable asset would equal the Treasury's best estimate of true economic depreciation; the investment tax credit would be dropped; real capital gains would be taxed at the regular income tax rate; and half of corporate dividends would be deductible at the corporate level. The indexation of inventory gains, the removal of the tax credit, and the proposed tax depreciation treatment would result in $\rho-\mathrm{d}$ equaling $r /(1-\tau)$ for all properties except owner-occupied housing, and the partial dividend exclusion would reduce discrepancies between the $r^{\prime} s$ for corporate and noncorporate investments. 
(see below). 7 Households under forty use far more debt (the average loan-tovalue ratio for first-time homebuyers in 1984 was 87 percent) and often make quite long-term housing decisions. It is the decisions of such households that we are attempting to model, and their present-value, weighted-average, loanto-value ratio is probably near two-thirds.

Based upon Ibbotson-Sinquefield calculations, we assume for corporate equities is 0.075 , and thus the risk premium for corporate assets, which have a one-third loan-to-value ratio, is $(1-b) \boldsymbol{\delta}=0.05$. The risk premium for depreciable real estate investors in properties with roughly 0.80 initial loan-to-value ratios is also about $0.075 .^{8}$ Because these real-estate assets have a mean loan-to-value ratio of two-thirds (initial ratio of near 80 percent), their risk premium is only 0.025 . For owner-occupied housing, a premium of 0.01 is assumed. This relatively low premium is consistent with owners having certainty with regard to their "vacancy" and "breakage" rates and thus greater certainty with respect to their net operating incomes than is the case with rental properties.

\section{Tax Parameters}

Tables 2 and 3 list the important business tax parameters under the laws existing in 1980 and 1981-85, in the proposed Treasury and Administration tax plans and in H.R. 3838 passed in December 1985. The 1981 Tax Act roughly halved depreciation tax lives and lowered the percentage of straight line for equipment and utility and residential structures, raised the percentage for industrial structures, and maintained straight-line for commercial real estate (straight-line is preferred over accelerated methods due to more onerous recapture provisions upon sale). 9 The 1981 Act promised more accelerated methods in 1985, but the 1982 Tax Act reneged on the promise and reduced the depreciable base for equipment by one-half the investment tax credit. The 1984 Act raised the tax life for structures, other than public utilities, back to 18 years and this was raised further to 19 years in late 1985. 
The Administration plan retreated from these principles in significant respects: all interest would continue to be deductible; investors in nondepreciable assets would have the option of paying taxes on-nominal capital gains at one-half of the regular income tax rate; tax depreciation would exceed economic depreciation; only one-tenth of dividends would be deductible; and, in order to make the plan revenue neutral, the indexation of inventory gains is dropped. Tax depreciation would be especially generous for equipment that continues to be classified as 3 or 5 years and for public utility structures; allowable depreciation would exceed that under current law even at zero inflation. However, most 5-year equipment would be reclassified as 6,7 and even 10-year equipment. For industrial structures, tax depreciation would be more favorable only at inflation rates of roughly 5 percent or greater. The House bill has double declining balance depreciation for equipment and public utility structures, but longer depreciation tax lives than the Administration plan and only partial indexation of the depreciable base (half of the inflation above 5 percent) results in significantly less favorable overall depreciation. The partial dividend exclusion is of little import in our model because only 10 percent of equity financing is assumed to be from new share issues on which dividends are paid. (Dividends are saved initially by the retention of earnings, offsetting the future payment of dividends.) Thus $\gamma$ in the model is only 0.05 under the Treasury plan and 0.01 under the Administration plan, 10 percent of the 50 and 10 percent exclusions, respectively.

In our analysis of owner-occupied housing, we consider households at five different income levels in order to deduce the tax rates that are representative of households in five income ranges. The ranges for 1980 are listed in the top panel of Table 4; the 1985 ranges, which exceed those from 1980 by a third to two-fifths to reflect the growth in nominal incomes per household, are listed in the lower panel. (The exact income levels for which the tax rate calculations were performed are listed in parentheses.) The 
state-and-local and federal tax rates relevant to the quantity-demanded decision in 1980 are listed in the next two columns in the top panel, and the total tax rate -- the federal plus the state times one minus the federal -- is shown in the fourth column. For the highest income class, $x_{j}=x_{e}$. For the other classes, the $x_{j}$ equal 8 (equals 1 except in the Treasury plan) times the $\tau_{j}$ shown in the table. The interest indexation feature of the Treasury plan $(B<$ 1) has a major impact on the opportunity cost of own equity financing of owner-occupied housing (as well as on tax-exempt yields -- see note a to Table 3). 11 The last column is the tax rate relevant to tenure choice (a weighted average of the average tax rates applied to debt and equity). ${ }^{12}$ The lower panel lists similar calculations for 1985 incomes under current law and the tax reforms, the Treasury and Administration proposals reflecting the nondeductibility of state and local taxes.

II. The Capital Allocation Model ${ }^{13}$

An Overview

The basic model allocates a fixed private capital stock among various classes of nonresidential and residential capital. The allocation depends on the rental or user costs for the capital components, the price elasticities of demand with respect to the rental costs, and the elasticities of homeownership with respect to the cost of owning versus renting. The interest rate adjusts in response to tax changes so as to maintain the aggregate demand for capital at its initial level. The fixed capital stock assumption implies zero interest elasticity of saving.

Table 5 lists the distribution of the U.S. capital stock at the end of 1984 by type. A number of simplifying assumptions are made in the construction of the model. Because well over 90 percent of inventories are held by corporations and nearly 90 percent of rental housing is held by noncorporate business, we assume that each of these assets is held totally by corporate and 
noncorporate business, respectively. While equipment is depreciable over 3 or 5 years, about 95 percent of it is classified as 5 -year. We treat all equipment as 5-year. Because public utility structures (which are virtually all corporate) are depreciated over a shorter life that other structures and are eligible for the investment tax credit, they are treated separately. With these assumptions and distinctions, the capital shares in 1980 and 1984 are those listed in the percent share columns. The last column indicates that a reallocation of capital toward equipment and commercial real estate occurred between 1980 and 1984 .

Current law treats owner-occupied housing differently depending upon the tax position of the owner, with higher income households paying a lower rental cost owing to their lower after-tax financing rate. Thus it is necessary to distribute the housing stock across households at different income levels. The distribution depends upon the number of owners within each income range as well as the income range and the rental costs for each of the ranges.

For all assets except rental housing, the demand for the asset is determined by the investor in the asset, be it a corporation, unincorporated business or a household. For rental housing, demand is determined by renters, based upon their incomes and the market rent level. Thus, the total quantity of rental housing, like the total quantity of owner housing, is built up as the sum of the demands by households in different income brackets.

Table 6 indicates divisions of the demand for housing across the same five income classes listed in Table 4, with a lower income class of all renters added. The first three columns contain the income classes selected, the division of $80 \mathrm{million}$ households across these classes, and the assumed ownership rates for these classes. Columns 4 and 5 give the distribution of the income of owners and renters across these classes. Column 4 is the product of the first three columns divided by the sum of the products. In the column 5 calculation, the fraction of households owning is replaced by the fraction 
renting. Columns 6 and 7 give the distribution of the owned and rented stocks. These distributions and the ownership rates were calculated from model equations described below. Based upon 1980 data, the equations imply an aggregate ownership rate of 0.59 , slightly below that existing then.

\section{Model Equations}

The model explains 13 rental costs: seven for the different types of nonresidential capital, five for owner-occupied housing of households in our five income ranges, and one for rental housing. As discussed in the previous section, these costs depend on numerous provisions of the tax law, the depreciation rate of the asset, the expected inflation rate and the level of interest rates in the economy. Moreover, rental costs for household tenure choice decisions $\left(\hat{\rho}_{j}\right)$ differ from those for quantity demanded decisions ( $\rho_{j}$ ) because the tax rates relevant to the after-tax financing rates differ (see Table 4). We summarize the rental cost equations as

$$
\begin{aligned}
& \rho_{k}=\rho_{k}\left(\operatorname{tax}_{k}, d_{i}, \pi, i\right) \\
& \rho_{j}=\rho_{j}\left(\operatorname{tax}_{j}, d_{j} \pi, i\right) \\
& \rho=\rho\left(\operatorname{tax}, d_{,}, i\right) \\
& \hat{\rho}_{j}=\hat{\rho}_{j}\left(\operatorname{tax} \hat{x}_{j}, d_{j}, \pi, i\right) .
\end{aligned}
$$$$
(1)-(7)
$$

There are seven demand equations for nonresidential capital (NK) : corporate inventories, corporate and noncorporate 5-year equipment, 10- and 15-year public utility structures, and other corporate (industrial) and noncorporate (commercial) structures. Assuming that production functions are Cobb-Douglass [Berndt(1976)], these demand equations can be written as 


$$
\mathrm{NK}_{\mathrm{k}}=\mathrm{z}_{\mathrm{k}} / \rho_{\mathrm{k}^{\prime}}
$$

where the $\mathrm{Z}_{\mathrm{k}}$ are constants (depending on given outputs) and the $\rho_{\mathrm{k}}$ are the rental costs.

The housing demand and tenure choice equations come from the specification of a translog indirect utility function for households (King, 1980) and the empirical application of it to the ownership decision (Hendershott and shilling, 1982). The estimated odds of owning equation was

$$
\log \frac{O_{j}}{1-O_{j}}=-3.846 \log \left[\hat{\rho}_{j} /(\rho / .9)\right]-.383\left[\left(\log \hat{\rho}_{j}\right)^{2}-(\log \rho / .9)^{2}\right] .
$$

The division by 0.9 reflects the fact that those renting have to pay more than the user cost to offset the revenues lost from vacancies. Taking antilogs and solving, the ownership rates for the five highest income classes are

$$
o_{j}=e^{L} j /\left(1-e^{L} j\right)
$$

where the $L_{j}$ equal the right-hand side of the $\log \left[0_{j} /\left(1-0_{j}\right)\right]$ expression. The ownership rate for the lowest income class is assumed to be zero.

There are also five demand equations for owner housing and six for rental housing based on our six income classes, the lowest of which consists solely of renters. These demands are the products of the demands per owning/renting household and the number of owning/renting households. The specific form of the equations comes from application of Roy's identity to the indirect utility function and substitution from the estimated odds of owning equation. For owner housing $(\mathrm{OH})$, the demand equations are 


$$
\mathrm{OH}_{j}=o_{j} \mathrm{HH}_{j} \mathrm{Z}_{j}\left(3.846+.766 \log \rho_{j}\right) / \rho_{j}
$$

where $o_{j}$ is the ownership rate for the $j$ th class, $\mathrm{HH}_{j}$ is the number of households in the jth class, and the $z_{j}$ are constants which are proportional to the incomes of representative households in the classes. For rental households (RH), the equations are

$$
\mathrm{RH}_{j}=\left(1-\mathrm{O}_{j}\right) \mathrm{HH}_{j} \mathrm{Z}_{j}(3.846+.766 \log \rho / .9) /(\rho / .9) .
$$

where $\rho / .9$ is the rental price facing all renting households.

Lastly, equality between the sum of the demands and the existing capital stock determines the level of interest rates in the economy:

$$
\Sigma \mathrm{NK}_{\mathrm{k}}+\Sigma \mathrm{OH} \mathrm{j}_{\mathrm{j}}+\Sigma \mathrm{RH}_{\mathrm{j}}=\mathrm{K} \text {. }
$$

Given a specific tax regime and assumed levels of the interest and expected inflation rates, the $\rho_{k}, \rho_{j}, \hat{\rho}_{j}$, and $\rho$ can be computed. The Nk were $_{k}$ listed in Table 5, and the $\mathrm{OH}_{j}$ and $\mathrm{RH}_{j}$ are products of the total residential structures share reported in Table 5 and the fractions of those shares listed in Table 6. The $\mathrm{o}_{j}$ and $\mathrm{HH}_{j}$ were also listed in Table 6 . The $\mathrm{z}_{\mathrm{k}}$ can be calculated from equations (19)-(25); the $z_{j}$ are proportional to the incomes of the representative households in the classes and are scaled such that the sum of the demands for owner and rental housing (as proportions of the total capital stock) equals the existing housing stock (as a proportion of total capital).

A number of simplifying assumptions of the model should be noted. These include, but are not limited to, constant risk premia and infinite real supply price elasticities (zero transactions costs) and thus constant real asset prices. Simulated changes in the allocation of capital are thus meant to 
indicate how the composition of net investment would be altered by tax (and inflation) changes, not precisely what the new capital allocation will be five or ten years following a change in tax regime or inflation rate.

III. The Changing Tax and Inflation Environment, 1980-85

In this section we deduce the impact of the Economic Recovery Tax Act of 1981 on interest rates, the homeownership rate, and the allocation of real capital. Because over four years have now passed since the passage of ERTA, we can also "test" the underlying simulation model by comparing the simulated impact of the Act with observed events. This requires analyzing all major disturbances that have occurred since early 1981, not just the passage of ERTA. The first part of this section simulates the impacts of ERTA alone and of ERTA combined with a decline in the inflation rate. The second part compares the simulated impacts with observed changes in recent years. ERTA and Disinflation

The disturbance of major interest to us is the passage of the Economic Recovery Tax Act of 1981. As documented in Section I, this Act substantially enhanced tax depreciation allowances and lowered personal tax rates. A second major phenomenon in the early 1980 s was a reduction in the inflation rate. In 1980, inflation was proceeding at a 10 percent rate; by 1984 and 1985 , the rate was slightly below 4 percent. We presume that the decline in the long-run expected inflation rate was a smaller drop from 8 to 5 percent, the 10 percent reflecting temporarily surging energy prices and declining value of the dollar and the 4 percent rate reflecting the reverse.

The first column of Table 7 lists the assumed 1980 interest and inflation rates, the model simulated homeownership rate, and the 1980 distribution of the capital stock listed in Table 5. The second column contains the model simulation results for these variables (except for the assumed constant inflation rate) based upon enactment of ERTA. The third column reflects ERTA 
(and the 1982 reduction in the depreciation base by half of the investment tax credit) plus a decline in the inflation rate to 5 percent. These simulations are discussed in turn.

Comparing the second and first columns, the more favorable tax treatment of depreciable property provided by ERTA raises the demand for such capital at pre-ERTA interest rates. While the cut in personal tax rates lowers the demand for owner-occupied housing -- the after-tax financing rate and opportunity cost of owner equity rise -- the decline is not nearly sufficient to offset the increased demand for other capital, so interest rates rise. ${ }^{14}$ The computed increase is just over a percentage point.

In spite of this increase, the hurdle rates for equipment, industrial structures and public utilities decline by $2 \frac{1}{2}, 1 \frac{1}{2}$ and 1 percentage points, respectively. Those for depreciable real estate are roughly unchanged (the

$\because$ interest rate increase and more generous depreciation roughly offsetting), while those for inventories and owner-occupied housing increase by just over a percentage point. The homeownership rate declines by $4 \frac{1}{2}$ percentage points. On net, the capital stock is shifted sharply from residential to nonresidential uses, with the aggregate housing stock declining by $9 \frac{1}{2}$ percent. of the nonresidential components, the increases are roughly 10 percent for equipment and industrial structures and about 5 percent for public utilities and commercial real estate. Inventories decline by one percent.

Incorporating a 3 percentage point decline in the inflation rate sharply alters the results. Because the interest rate declines by roughly a point and a half for each point decline in inflation, disinflation is good for owneroccupied housing; the real after-tax financing rate will decline for households in tax brackets below 33 percent. Thus we see a 4 percentage point increase in the homeownership rate relative to the case of no decline in inflation. The total housing stock is roughly unchanged, however; the increase in owner-occupied housing is about offset by the decline in rental 
housing. The disinflation also induces a shift in the composition of structures, with corporate structures rising and highly-levered noncorporate structures declining (the advantages of debt are reduced at lower interest rates).

\section{A Comparison with Observed Changes}

Model simulations should not be expected to track observed economic changes closely. Simulations provide an estimate of where an economy in full equilibrium at the initial parameter values will eventually move in response to a specified disturbance (change in model parameters, structure or state of world). However, even if the model accurately characterizes the economy, the observed economic changes may differ from those implied by the model for two reasons. First, the economy may have been a significant distance from full equilibrium when the disturbance occurred. If the tendency toward this equilibrium differs significantly from the tendency created by the specified disturbance, the observed changes in the economy may not resemble the simulated changes. Second, disturbances other than those specified may have occurred. If these have impacts that correlate negatively in some respects from the specified disturbances, again the simulated changes may differ significantly from the actual changes. Nonetheless, simulations of the major disturbances to an economy should trace out the broad contours of subsequent economic events.

The principal phenomena that the model simulations would lead us to expect are:

(1) an increase in long-term interest rates until the decline in long-run expected inflation sets in,

(2) a shift from owning to renting, until the impact of the decline in longrun expected inflation is felt, and

(3) a shift from residential (and inventory) to nonresidential uses, especially equipment investment early on.

The correspondence of observed events with each of these expectations is discussed in turn. 
Table 8 contains data on the corporate bond rate and two measures of the December-to-December changes in the CPI: all items less food, energy and home purchase and finance and the new CPI X-I, which became the official CPI after 1982. The major difference between the inflation series is the exclusion of food and energy from the former; these components rose particularly rapidly in the late 1970s and 1980 and slowly in the 1982-84 period. The bond rate certainly jumped in 1981 and 1982. The rate exceeded 14 percent for the entire July 1981-July 1982 period (was over 15 percent in september-October 1981 and January-February 1982) before plummeting by year end 1982. The one-year inflation rate also plummeted in 1982 and has continued to drift downward since then. A lagged response of long-run expected inflation to short-run observed inflation would suggest a gradual decline in the former throughout the 1983-85 period. In general, we would anticipate that the 1981-84 data changes would - largely reflect the ERTA simulation, with post-1984 data gradually reflecting the ERTA plus disinflation simulation.

The correspondence between simulations of the homeownership rate and observed changes is especially tenuous because the changes are quite sensitive to shifts in the age composition of the population. To illustrate, the aggregate rate rose by only $3 \frac{1}{2}$ percentage points between 1960 and 1979 , even though ownership rates of every age cohort rose by close to 10 percentage points. The reason for this discrepancy was a surge in young households (under 25) who tend to rent and a relative decline in older households (over 34) who predominantly own. The data in Table 8 illustrate the dependency of ownership on age. Old households tend to be less mobile, have higher incomes, and be wealthier, characteristics that lower the effective cost of owning.

The data in Table 9 refer to married couples only in order to abstract from other demographic effects, but the results would be roughly comparable for all households. As can be seen, a shift to homeownership occurred for all age groups between 1974 and 1980 and even continued after 1980 for households over 
age 54. For younger more mobile households who are more likely to be making tenure decisions based upon current economic conditions, 1980 was a watershed for ownership. In just three years, the ownership rate for those under 40 declined by 4 to $6 \frac{1}{2}$ percentage points, just as would be anticipated under the ERTA scenario. Whether the offsetting disinflation impact will be observed in later data is uncertain.

The ERTA simulation suggests a large decline in residential structures and an increase in equipment. These shifts are reflected in the 1984 data (see Table 4) with the equipment share already up by half the predicted 11 percent increase and residential structures down by one-quarter of the estimated $9 \frac{1}{2}$ percent decline. Much of the observed decline is certainly due to the changed behavior of younger households. If this change were allowed to work its way through to older households in a long-run adjustment, the decline in residential structures would approach the large simulated decline.

- The observed reallocation of nonresidential structures does not correspond nearly as well with the hypothesized partial movement to the simulated new equilibrium. Commercial structures have already increased in share by more than the simulated amount, while public utility structures have declined significantly as a share of the total capital stock (not increased as the simulation predicts) and industrial structures have risen little. Even here, plausible explanations are available. The expansion of the rehabilitation tax credit in ERTA, which is not reflected in the simulations, must have significantly inareased the value of commercial structures; moreover, high vacancy rates suggest that commercial structures have been over built -- the new equilibrium could entail a less than four percent increase in this share. As for the relative decline in public utility structures, energy conservation in response to the sharp run up in real energy prices in the 1979-81 period and the well-publicized problems of the nuclear power industry are likely causes. Dwelling on such explanations is probably not worthwhile; 
the important fact is that observed data, on the whole, are not inconsistent with the ERTA model simulation. 15 Thus, the simulation model appears to be a reasonable vehicle for analyzing the impact of proposed tax reforms.

IV. Capital Allocation Under Current Law and Proposed Tax Reforms

The likely impacts of the Treasury and Administration tax reform proposals and the House bill on the level of interest rates, rental user costs, capital shares, and the homeownership rate are calculated in this section. We begin with a comparison of the risk-adjusted net user costs and interest rates under current law and the reforms and then turn to the capital stock effects. The analysis presumes 5 percent inflation. The sensitivity to inflation of various tax regimes is then examined, and efficiency losses from the misallocation of capital under the regimes are calculated.

Five Percent Inflation: Net Rental Costs

- The risk-adjusted net (of depreciation) rental costs for alternative investments are reported in Table 10 for current law and three reforms. (The risk adjustment is 0.04 for nonreal estate assets and 0.015 for depreciable real estate.) The interest rate (risk-free) under current law is presumed to be 10 percent (slightly above the $9 \frac{1}{2}$ percent model simulation of a 5 percent inflation world with ERTA tax law). The first numbers (those not in parentheses) given for the reforms are based upon the listed model-computed interest rates; the numbers in parentheses presume an unchanged 10 percent interest rate.

Under a neutral tax system, the risk-adjusted net hurdle rates would be the same for all assets. As can be seen, this is far from true under current law. The tax-favored assets are housing of high-income owners and noncorporate equipment. The tax-penalized assets are corporate structures, especially industrial structures that receive no tax credit, and inventories, whose inflationary gains are not indexed (with $\tau_{\pi}=0.7 \tau, \tau=0.5$ and $\pi=0.05$, the inflation tax raises the user cost by 0.035). More generally, corporate 
investments are penalized relative to noncorporate; less-leveraged investments are penalized relative to more-leveraged investments; and risky assets are penalized relative to less risky assets (Bulow and Summers, 1984). The over three and a half percentage point difference in net hurdle rates for industrial and rental structures reflects all three penalties. The largest penalty is the difference in asset risk, 0.05 for nonreal estate versus 0.025 for real estate, which accounts for 2 of the $3 \frac{1}{2}$ points. The corporate (double taxation) penalty is the smallest, accounting for only $\frac{1}{2}$ of the $3 \frac{1}{2}$ points because the taxation of corporate equity at the personal level is relatively light under the new view of corporate financing.

The Treasury plan greatly reduces the difference in risk-adjusted net hurdle rates among corporate assets by eliminating the inventory tax and the investment tax credit. All hurdle rates move toward that for industrial structures. The gross hurdle rate (net plus depreciation rate plus 0.04) for equipment rises by 14 percent and that for public utility structures rises by 8 percent, while that for inventories (with their 100 percent depreciation) falls by 3 percent. However, the plan increases the advantages of real estate. While the hurdle rates for depreciable properties are roughly unchanged (at 3 points below those for corporate assets), those for owner-occupied housing decline significantly; the 2.6 percentage point fall in the level of interest rates swamps the loss of the property tax deduction and the reduction in rates at which interest is deductible.

The increased advantage of owner-occupied housing stems from two factors: removal of tax advantages for business capital (especially the investment tax credit) and the introduction of an additional advantage for owner-occupied housing (the nonindexation of mortgage interest expense). The data in the third column of Table 10 are calculations assuming the Treasury plan were amended to include indexation of home mortgage interest expense. As can be seen, full indexation lowers the interest rate by another 30 basis points and the hurdle 
rates for business investments by 40 basis points. In contrast, the declines in the hurdle rates for middle-income owner-occupied housing are reduced by 25 basis points, and high-income owner-occupied housing faces a 50 basis point rise in hurdle rate.

The Administration plan drops interest indexation (and thus the new advantage for owner-occupied housing), deletes inventory indexation (in the revisions needed to achieve revenue neutrality), and "gives back" part of the investment tax credit by accelerating depreciation deductions for equipment and public utilities relative to economic depreciation; the present value of a dollar of depreciation on 5-year equipment increases from 76 to 85 cents, while that for 15-year public utilities rises from 50 to 76 cents or by over 50 percent. The latter change is so generous that the investment hurdle rate actually declines in spite of the loss of the ITC. With these changes, the level of interest rates falls by only 60 basis points, and the net result is a tax system that is less tilted toward high-income owner-occupied housing than current law.

The House bill postpones depreciation deductions, except on equipment, even more than the Treasury plan and does not index depreciation deductions unless inflation exceeds 5 percent. As a result of these changes and the removal of the investment tax credit, the aggregate demand for capital falls sharply and a 125 basis point decline in the level of interest rates occurs, a decline which significantly lowers the cost of owner-occupied housing at all except the very highest income levels. Like the Treasury plan, the House bill would tend to equalize net user costs across corporate investments.

As discussed, the model computes the level of interest rates that would maintain the aggregate demand for capital (net investment in a growth context) at its prereform level. However, a decline in U.S. interest rates would represent a decline in after-tax returns to foreigners unless foreign countries cut their marginal tax rates on interest income or move their interest rates 
pari passu with those in the U.S. As a result capital would flow out of the U.S. and domestic interest rates would not need to fall as much to bring the demand and supply of capital in the U.S. into balance. In the extreme case of no adjustment in foreign taxes or interest rates and prefectly elastic international capital flows, U.S. interest rates would not fall at all but the U.S. capital stock would, the fall being greater the larger is the decline in interest rates computed from the fixed-capital stock model. ${ }^{16}$ A more balanced view would incorporate less than perfectly elastic capital flows and significant changes in foreign interest rates in response to movements in U.S. rates. Thus a fall in foreign demand for U.S. capital would tend to dampen the decline in U.S. rates, but not eliminate it.

To indicate the sensitivity of the relationships among the adjusted net rental costs to the computed interest rate declines, rental costs based upon no rate decline have been computed and are listed in parentheses in Table 10. With higher (than the model-computed) interest rates, the rental costs are higher. For the Administration and House reforms, the relationships among the costs are little affected. For the Treasury plan, the already strong bias toward owneroccupied housing is magnified because all home mortgage interest is deductible whereas only the real component of interest financing other investments is. Five Percent Inflation: Capital Stock Impacts

The data in Table 11 suggest how the capital stock would be reallocated under the various reforms. These reallocations follow fairly directly from the realignment of investment hurdle rates just discussed. Removal of the inflation tax raises inventories, while the loss of the investment tax credit tends to shrink equipment and utilities, although utilities would actually rise in response to the far more generous depreciation allowances of the Administration plan. The Treasury and Administration reforms have sharply different impacts on the three types of structures. Under the Treasury plan, residential structures rise by 8 percent, while industrial and commercial structures are unaffected. 
Under the Administration plan, the reverse is true; residential structures are roughly unchanged while industrial and commercial structures rise by 8 percent. Moreover, the homeownership rate rises by 6 percentage points under the Treasury plan, but falls by 4 points under the Administration plan. The reallocations under the House bill are close to those of the Treasury plan, although the increase in the homeownership rate is only $2 \frac{1}{2}$ percentage points.

In general, an across the board cut in tax rates would be expected to have a negative impact on owner-occupied housing, the income from which is not taxed. This impact would be reinforced by a loss of the deductibility of property taxes on primary residences. Thus, the homeownership rate would decline, as would the share of structures in residential use. The simulated effect of the Administration plan corresponds to these expectations. The inverted effect of the Treasury plan follows from its interest indexation provision and the sharp decline in interest rates (largely in response to the indexation). A decline in interest rates is more beneficial to investors in low tax brackets than to those in high brackets because the investor receives more of the rate decline (and the Treasury receives less). Thus a sharp decline in interest rates is particularly beneficial to housing demanded by low and middle income owners. This factor is exaggerated in the Treasury plan by the exemption of home mortgage interest expense from the interest indexation feature. Thus housing of owners at all income levels (but especially at lower incomes) increases, and the homeownership rate jumps. The demand for owner-occupied housing would also rise under the House bill. This reflects the absence of a cut in the tax rates relevant to the quantity-demanded decision of owners with incomes under $\$ 100,000$ (see Table 4), the continued deductibility of property taxes, and the sharp 125 basis point decline in interest rates. 


\section{Inflation Neutrality}

Next we consider the impact of inflation under the various tax regimes by simulating an increase in inflation from zero to 10 percent. Inflation is quite negative for owner-occupied housing under current law because the average tax rate at which expenses are deductible is significantly less for owner housing (except for owners with very high incomes) than for other capital. Thus, the real after-tax interest rate paid by owners tends to rise, while that for other capital falls (see Titman, 1982 and Follain, 1986). ${ }^{17}$ on the other hand, inflation is very positive for depreciable real estate because the advantages of debt are magnified at higher interest rate levels. Thus the increase in inflation lowers the homeownership rate by 11 percentage points (the first column of Table 121, and raises the demand for both rental and commercial structures, the latter by 19 percent. The total housing stock increases because the stimulus to renter housing outweighs the negative impact on owner housing. With real estate expanding, the other capital components must decline. As can be seen, $\mathrm{di} / \mathrm{d} \pi=1.46$, midway between the nontax (unity) and $\operatorname{tax}[\mathrm{di} / \mathrm{d} \pi=1 /(1-$ T) 2] Fisherian values.

The Treasury plan makes a serious attempt at achieving inflation neutrality by setting tax depreciation equal to economic depreciation and indexing capital gains, depreciation allowances and interest. Unfortunately, the plan fails badly. To understand the failure, it is best to consider first the impact of an increase in inflation in a fully-indexed variant of the Treasury plan, i.e., one in which home mortgage interest expense is also indexed. The data in the second column of Table 12 show this impact. Increases in inflation are generally favorable for the sector with the highest tax rate (noncorporate business has a tax rate of 0.41 versus 0.37 for the corporate sector) because the after-tax interest rate rises least. The aggregate homeownership rate declines because the negative impact on lower income (tax) households outweighs the positive impact on high income households. The 
interest rate rises by more than the increase in inflation because of imperfect indexation; under our assumptions, only a third of interest is real at 5 percent inflation [(7.42-5)/7.42], but the Treasury indexation formula would treat six-elevenths as real (see note 10). With some inflationary interest being taxed, the interest rate responds more than one-for-one to inflation. Nonetheless, the fully-indexed variant of the Treasury plan is significantly less sensitive to inflation than current law; more specifically the sharp tilt toward depreciable real estate is greatly dampened.

Exclusion of home mortgage interest from the indexation provision changes the impact of inflation enormously. Homeownership and the demand for owneroccupied housing are greatly stimulated by inflation because the real-after tax financing rate for even our lowest income owning households declines. The surge in housing is matched by declines in all other capital types. The actual Treasury plan proposed is even less inflation neutral than current law. The next to the last column in Table 12 shows the impact of inflation on capital allocation under the Administration tax plan. Just as under current law, the homeownership rate would be significantly lowered by inflation. However, the stimulation for depreciable real estate and constriction of nonresidential capital would be far less. The Administration plan is thus significantly more inflation neutral than current law. The last column suggests that the House bill would be marginally more neutral than current law. Efficiency Losses

The differences in the risk-adjusted net rental costs in Table 10 provide a general indication of the misallocation of capital under the various tax laws. A single efficiency loss number for each tax regime is computed from the Harberger equation: 


$$
\text { LOSS }=\frac{1}{2} \sum_{j}\left(\operatorname{EFFADJ}_{\rho}-\operatorname{ADJ}_{j}\right)\left(\mathrm{CAP}_{j}-\mathrm{EFFCAP}_{j}\right),
$$

where the $A D J \rho_{j}$ 's are the risk-adjusted net user costs listed in Table 10 , EFFADJ $\rho$ is the single risk-adjusted net user cost $(0.0406)$ that when used to obtain gross user costs equates the sum of the demands for capital to the aggregate stock, the $\mathrm{CAP}_{j}$ are the likely percentage capital stocks under a given tax law (listed in Table 13), and the EFFCAP $j$ are the percentage allocations when the gross user costs are based on EFFADJ $\rho$. The efficient allocation of capital is listed in the first column of Table 13 .

The efficiency loss under current law, listed at the bottom of Table 13, is roughly 0.12 percent of the capital stock or about 0.25 percent of GNP. 18 The major source of the loss is 10 percent too much residential capital (largely offset by 24 percent too few industrial structures and 12 percent too few utility structures). 19 The widely-cited overinvestment is equipment is only 3 percent; while substantial overinvestment in equipment exists relative to corporate structures, overinvestment relative to capital generally is minor. of the three reforms, only the Administration plan reduces the efficiency loss, and the reduction is a sharp 50 percent. This is achieved by both a better allocation between residential and nonresidential capital (the overinvestment in residential capital is reduced from 10 to 8 percent) and better allocations within the residential and nonresidential sectors. The difference between the net user costs for the highest and lowest income owning households is reduced from 0.029 to 0.018 , and the large underinvestment in corporate structures is reduced significantly.

The Treasury plan and the House bill would increase the efficiency loss by 53 and 36 percent, respectively, the principal reason being the further overinvestment in residential capital (18 and 17 percent versus the current 10 percent). Not only do these bills remove the investment tax credit for equipment and utilities, but they reduce the value of depreciation deductions. 
The greater efficienty loss under the Treasury plan relative to the House bill is attributable to a substantial increase in the existing bias in favor of owning over renting. This, in turn, is due to the great advantage of debt financing of owner-occupied housing given by the partial taxation of interest income but full deduction of home mortgage interest expense. The fully-indexed Treasury variant (only real mortgage interest expense is deductible) leads to a smaller increase in residential capital, a better allocation within residential, and thus a negligible 6 percent increase in the efficiency loss.

Efficiency losses have also been calculated at different inflation rates. The losses under all tax regimes are lower at a zero inflation rate and greater at 10 percent inflation. For current law, the loss is 12 percent less at zero inflation and 37 percent greater at 10 percent inflation. The efficiency loss under the Administration plan is roughly half that of current law over the entire inflation range examined. At zero inflation, the losses under the Treasury plan and House bill are virtually identical to those under current law. At higher inflation rates the losses, especially under the Treasury plan, increase relative to current law; at 10 percent inflation the loss under the Treasury plan is nearly double that under current law. Such is not the case with the fully-indexed Treasury variant; its loss at 10 percent inflation is slightly less than that of current law.

\section{v. Summary}

The paper begins with presentation of a methodology for computing annual rental costs of capital or investment hurdle rates under any tax regime. Tax law over the 1980-84 period is specified and the provisions of the Treasury and Administration tax reform proposals and HR 3838 are described. A model is then constructed to allow calculation of the impact of changes in tax regimes and/or expected inflation on interest rates and the allocation of real capital. The model allocates a fixed private capital stock among various classes of 
nonresidential and residential capital, depending upon the rental costs for the capital components, the price elasticities of demand with respect to the rental costs, and the elasticities of homeownership with respect to the cost of owning versus renting. The interest rate adjusts in response to tax/inflation changes so as to maintain the aggregate demand for capital at this initial level. Simulation of the Economic Recovery Tax Act of 1981 suggests an increase in interest rates, a decrease in homeownership, and a shift in capital from residential to nonresidential uses, especially equipment. Data since 1980 are consistent with these "forecasts" when one abstracts from the impact of the decline in inflation on interest rates after the middle of 1982 . The decline in ownership is restricted to younger (under 40) households who are likely to be making tenure decisions based upon current economic conditions. The general correspondence between these simulations and recent economic events suggests that the simulation model is appropriate for analyzing the impact of proposed táx reforms.

Under a neutral tax system, the risk-adjusted net (of depreciation) investment hurdle rates would be the same for all assets. This is far from true under current law. The tax-favored assets are housing of high-income owners and noncorporate equipment. The most tax-penalized asset is inventories, whose inflationary gains are not indexed. Corporate structures are also penalized, especially industrial structures that receive no tax credit. More generally, corporate investments are penalized relative to noncorporate; less-leveraged investments are penalized relative to more-leveraged investments; and risky assets are penalized relative to less risky assets.

The Treasury plan greatly reduces the difference in risk-adjusted net hurdle rates among corporate assets by eliminating the inventory tax and the investment tax credit. However, the plan increases the advantages of real estate. While the hurdle rates for equipment and utilities rise to that for industrial structures, those for owner-occupied housing decline significantly in 
response to a 2.6 percentage point decline in interest rates (and the nonindexation of home mortgage interest expense). The Administration plan drops interest indexation and accelerates depreciation deductions for equipment and, especially, public utilities relative to economic depreciation. With these changes, the level of interest rates falls by only 0.6 percentage points, and the demand for owner-occupied housing by middle and high income households declines. In contrast, the House bill has even less general depreciation allowances than current law. Consequently, hurdle rates for equipment and utilities rise sharply, while the 125 basis point decline in interest rates lowers hurdle rates for owner-occupied housing. The basic results are the same in the absence of interest-rate declines; hurdle rates decline relatively for owner-occupied housing under the Treasury plan and House bill, but not under the Administration plan. That is, whether rates decline or not the former two roposals would tilt the playing field toward owner-occupied housing, the most tảx formed asset under current law.

Reallocation of the capital stock follows fairly directly from the realignment of investment hurdle rates. Removal of the inflation tax raises inventories, while the loss of the investment tax credit tends to shrink equipment and utilities, although utilities would actually rise in response to the far more generous depreciation allowances of the Administration plan. While the specific provisions of the Treasury plan and the House bill differ widely, these two reforms should be expected to have remarkably similar impacts on capital allocation. In contrast, the Administration plan would have a sharply different impact on the three types of structures. Under the Treasury and House plans, residential structures rise by 8 percent, while industrial and commercial structures are largely unaffected. Under the Administration plan, the reverse is true. Moreover, the homeownership rate rises significantly under the Treasury and House plans, but falls by 4 points under the Administration plan. 
Inflation is quite negative for owner-occupied housing under current law because the average tax rate at which expenses are deductible is significantly less for owner housing than for other capital. Thus, the real after-tax interest rate paid by owners tends to rise with an increase in inflation, while that for other capital falls. On the other hand, inflation is very positive for depreciable real estate because the advantages of debt are magnified at higher interest rate levels. While an increase in inflation lowers the homeownership rate, commercial structures increase sharply. Moreover, total housing increases because the stimulus to renter housing outweighs the negative impact on owner housing. With real estate expanding, the other capital components decline.

The Treasury plan makes a serious attempt at achieving inflation neutrality by setting tax depreciation equal to economic depreciation and indexing capital gains, depreciation allowances and interest. Unfortunately, the plan fails badly. While a fully-indexed variant of the Treasury plan would be less sensitive to inflation than current law, exclusion of home mortgage interest expense from the indexation provision of the Treasury plan reverses this result. Homeownership and the demand for owner-occupied housing are strongly stimulated because the real-after tax financing rate for even low income owning households declines. The surge in housing is matched by declines in all other capital types.

Just as under current law, the homeownership rate would be significantly lowered by inflation if the Administration plan or House bill were in place. However, the stimulation of depreciable real estate and the constriction of nonresidential capital would be far less under the Administration plan. The Administration plan is thus significantly more inflation neutral than current law; the House bill would be mildly more neutral.

Of the three plans, only that proposed by the Administration would lead to a more efficient allocation of capital, i.e., one that is less biased toward high-income housing and away from corporate structures. The current efficiency 
loss would be roughly halved. The Treasury plan, while equating hurdle rates across corporate assets, would greatly increase the current efficiency loss at positive inflation rates by stimulating additional overinvestment in housing. The increases in the loss would be roughly 50 percent at 5 percent inflation and nearly 100 percent at 10 percent inflation. The House bill, too, would increase the efficiency loss, and for the same reason, but the increase would be a smaller 25 to 40 percent at inflation rates between 3 and 10 percent. 
FOOTNOTES

1. Earlier simulation analyses of ERTA include Gravelle (1982) and Hendershott and shilling (1982).

2. We do not consider the impact of imperfect loss offsets. For an analysis of these and other details of corporate taxation, see Auerbach (1983).

3. Because property taxes on owner-occupied housing are deductible, the tax saving from these taxes on a dollar of housing (assuming a property tax rate of $0.012)$ is subtracted from the right side of (1).

4. Optimal bond trading is discussed in Constantinides and Ingersoll (1984). Other sources of the low implicit yield in longer-term tax exempts are the greater risk of losses due to default and call on municipals relative to Treasuries and the 80 percent limitation of the portion of interest on indebtedness used to carry tax exempts that commercial banks can deduct.

5. While the explicit and implicit tax rates relevant to the quantity-demanded decision are marginal rates, those relevant to the decision of whether to own or rent depend on the average rates at which interest for the entire house purchase is deducted and on which the entire owner-equity investment would have been taxed (Hendershott and slemrod, 1983).

6. One million of the 1-4 unit properties in 1980 were no more than a decade old, as were 77,500 of the 5-49 unit properties and 22,700 of the over-50 unit properties. With $1.3,11$ and 160, respectively, as the average number of units in each of these three classes of properties, 63 percent of the total units no more than a decade old were in properties with 50 or more units. Because a 


\section{$-34-$}

significant number of the 1-4 unit properties were originally built for ownership, two-thirds to three-quarters of the newly-constructed rental units were probably in properties with 50 or more units.

7. Sixty percent of owning households with incomes under $\$ 15,000$ in 1983 had house-to-income ratios exceeding 4 , suggesting that the households were retired and did not have a mortgage. In contrast, eighty percent of owning households with incomes over $\$ 25,000$ had mortgages and only five percent with incomes above $\$ 25,000$ had house-to-income ratios above 4 .

8. The National Association of Homebuilders (1985, p.51) assumes a 14 percent value for $e$ when $\pi$ is six percent. This inflation rate translates into a taxexempt rate just above 8 percent in our model and thus a risk premium of about 6 percent. Price-Waterhouse has used an e of 16 percent in their calculations.

9. The 1981 act also expanded the investment tax credit slightly. Both this expansion and the more generous depreciation deductions were effective January 1,1981 .

10. The Treasury would assume a real interest rate of 6 percent and allow the deduction of (or would tax) only $6 /(6+\pi)$ of interest paid (or earned), where $\pi$ is the actual inflation rate in a tax year. Thus if inflation were 5 percent, only 55 percent of interest would be taxed and deducted. With zero inflation, all interest would be taxed and deducted; with 108 inflation only 38 percent would. (However, mortgage interest outlays on one's principal residence would be fully deductible.) 
11. Because only $55 \% / 38 \%$ of nominal interest income would be taxed in a five/ten percent inflation world, the tax rate relevant to own equity financing would be $55 \% / 38 \%$ of the marginal rates shown in Table 2 or the tax-exempt rate, whichever is less.

12. The methodology for computing these tax rates is discussed in Hendershott and Ling (1986).

13. The model is both an extension and simplification of that used by Hendershott and Shilling (1982) to analyze the Economic Recovery Tax Act of 1981. The extension is a more detailed treatment of nonresidential capital; the simplification is an exogenous specification of risk premia. Gravelle (1985) uses a somewhat similar model to analyze the Treasury plan. Fullerton (1985) analyzes the impact of the Treasury plan on effective tax rates.

14. Higher interest rates pulled in foreign capital, but the dampening effect of this inflow on rising interest rates is assumed to have been offset by increased Federal deficits.

15. Bosworth (1985) makes the somewhat contrary argument that business investment in recent years is not consistent with the passage of ERTA.

16. In simulations where the aggregate capital stock was determined endogenously as that consistent with the imposed 10 percent interest rate, the total capital stock falls by 15 percent in the Treasury simulation, 8 percent in the HouseBill simulation, and 3 percent for the Administration plan. 
17. This statement would seem to be at variance with the sharp shift to homeownership in the 1970s. The latter occurred because interest rates did not fully reflect expected general inflation and expected house price inflation likely exceeded expected general inflation by 2 to 3 percentage points.

18. This is an understatement of the loss because it does not take into account inefficiencies created by industry specific tax provisions or by tax-exempt financing of private purpose activities. Moreover, the gains from removing such inefficiences by, say, the Treasury plan are understated.

19. The loss is independent of the presumed risk premium associated with owner-occupied housing ( $\rho-d-\delta$ is independent of $\delta$ ) and is largely independent of its presumed loan-to-value ratio (under current law an advantage of debt financing exists only for high-income owners). 


\section{REFERENCES}

Auerbach, A.J., 1983, "Corporate Taxation in the United States," Brookings Papers on Economic Activity, 2, 451-505.

_._1979, "Wealth Maximization and the Cost of Capital," Quarterly Journal of Economics, 93, August, 433-446.

Berndt, E.R., 1976, "Reconciling Alternative Estimates of the Elasticity of
Substitution" Review of Economics and Statistics, February, 59-68.

Board of Governors of the Federal Reserve System, 1984, Balance sheets for the U.S. Economy, April.

Bosworth, B.P., 1985, "Taxes and the Investment Recovery," Brookings Papers on Economic Activity, 1, 1-38.

Bulow, J.I. and L.H. Summers, 1984, "The Taxation of Risky Assets," Journal of Political Economy, 92, 20-39.

Constantinides, G.M. and J.E. Ingersoll, Jr., 1984, "Optimal Bond Trading with Personal Taxes," Journal of Financial Economics, 13, September, 299-335.

Follain, J.R., 1986, "Another Look at Tenure Choice, Inflation and Taxes," Office of Real Estate Research Working Paper 24, University of Illinois, January.

Fullerton, D., 1985, "The Indexation of Interest, Depreciation, and Capital Gains: A Model of Investment Incentives," NBER Working Paper 1655, June. 
Gravelle, J.G., 1982, "Effects of the 1981 Depreciation Revisions on the Taxation of Income from Business Capital," National Tax Journal, 35, March, 120 . - 1985, "Assessing Structural Tax Revision with Economic Models: The Treasury Tax Proposals and the Allocation of Investment," Congressional Research Service, The Library of Congress, April 8.

Hall, R.E. and D.W. Jorgenson, 1967, "Tax Policy and Investment Behavior," American Economic Review, 56, June, 391-414.

Hendershott, P.H. and D.C. Ling, 1986, "Likely Impacts of the Administration Proposal and the House Bill," in J. Follain (ed.), Tax Reform and Real Estate, The Urban Institute.

Hendershott, P.H. and J.D. Shilling, 1982, "The Impacts on Capital Allocation of Some Aspects of the Economic Recovery Tax Act of 1981," Public Finance Quarterly, April, 242-273.

Hendershott, P.H. and J. Slemrod, 1983, "Taxes and the User Cost of Capital for Owner-Occupied Housing," Journal of the American Real Estate and Urban Economics Association, Winter, 375-393.

King, M.A., 1980, "An Econometric Model of Tenure Choice and the Demand for Housing as a Joint Decision," Journal of Public Economics, 14, 137-159.

Musgrave, J.C., 1984, "Fixed Reproducible Tangible Wealth in the United States, 1980-83," Survey of Current Business, August, 54-59. 
National Association of Home Builders, 1985, "Impacts of the President's Tax Proposal on Housing," July.

Titman, S.D., 1982, "The Effect of Anticipated Inflation on Housing Market Equilibrium," Journal of Finance, $37,827-842$. 
Table 1

Data on Ownership and Debt for Stock of Over-50 Unit Rental Properties

$1960 \quad 1970 \quad 1980$

\% ownership

$\begin{array}{lccr}\text { Individuals } & 21 & 22 & 18 \\ \text { Partnerships } & 14 & 36 & 56 \\ \text { Rental Corporations } & 49 & 29 & 12 \\ \text { Other } & 6 & 3 & 4\end{array}$

Mortgaged Properties

8 of Total Properties $\quad 90 \quad 93$

Median Loan-to-Value Ratio $\quad 54 \quad 67$

Properties with First Mortgage

(new or assumed) at Time of Purchase

8 of Mortgaged Properties 57

$57 \quad 81$

$\begin{array}{llll}\text { Median Loan-to-Value Ratio } & 83 & 87 & 87\end{array}$

Sources: U.S. Department of Commerce, Bureau of the Census, Residential Finance Sections of 1960, 1970 and 1980 Census of Housing. 
Table 2

Depreciation and Tax Credit Parameters

$\begin{array}{lrrrrr}8 \text { SL } & 2.0 & 2.0 & 1.5 & 1.0 & 2.0 \\ \text { Tax Life } & 11 & 21 / 30 & 37 & 37 & 32 \\ \text { Tax Credit } & .096 & .10 & 0 & 0 & 0\end{array}$

\section{1-85}

$\begin{array}{lcrrrr}8 \text { SL } & 1.5 & 1.5 & 1.75 & 1.0 & 1.75 \\ \text { Tax Life } & 5 & 10 / 15 & 15 b & 15^{b} & 15^{b} \\ \text { Tax Credit } & .10^{\mathrm{a}} & .10 & 0 & 0 & 0\end{array}$

\section{Treasury}

$\begin{array}{lccccc}\text { Depr. Rate } & .15 \text { (aver.) } & .08 / .05 & .03 & .03 & .03 \\ \text { Tax Life } & 5 \text { to } 24 & 24 / 38 & 63 & 6.3 & 63 \\ \text { Tax Credit } & 0 & 0 & 0 & 0 & 0\end{array}$

\section{Administration}

$\begin{array}{lcrrrr}8 S L & 1.62 & 1.54 / 1.7 & 1.12 & 1.12 & 1.12 \\ \text { Tax Life } & 6 \text { (aver.) } & 7 / 10 & 28 & 28 & 28 \\ \text { Tax Credit } & 0 & 0 & 0 & 0 & 0\end{array}$

\section{House Bill}

$\begin{array}{lcrrrr}8 S L & 2.0 & 2.0 & 1.0 & 1.0 & 1.0 \\ \text { Tax Life } & 8 \text { (aver.) } & 20 / 30 & 30 & 30 & 30 \\ \text { Tax Credit } & 0 & 0 & 0 & 0 & 0\end{array}$

$a_{\text {The }} 1982$ Tax Act reduced the depreciable base by one-half the tax credit. $\mathrm{b}_{\text {The }} 1984$ Tax Act raised the life from 15 to 18 years, and the 1985 Act raised it to 19. 
Table 3

Tax Rates and Deductibility Provisions

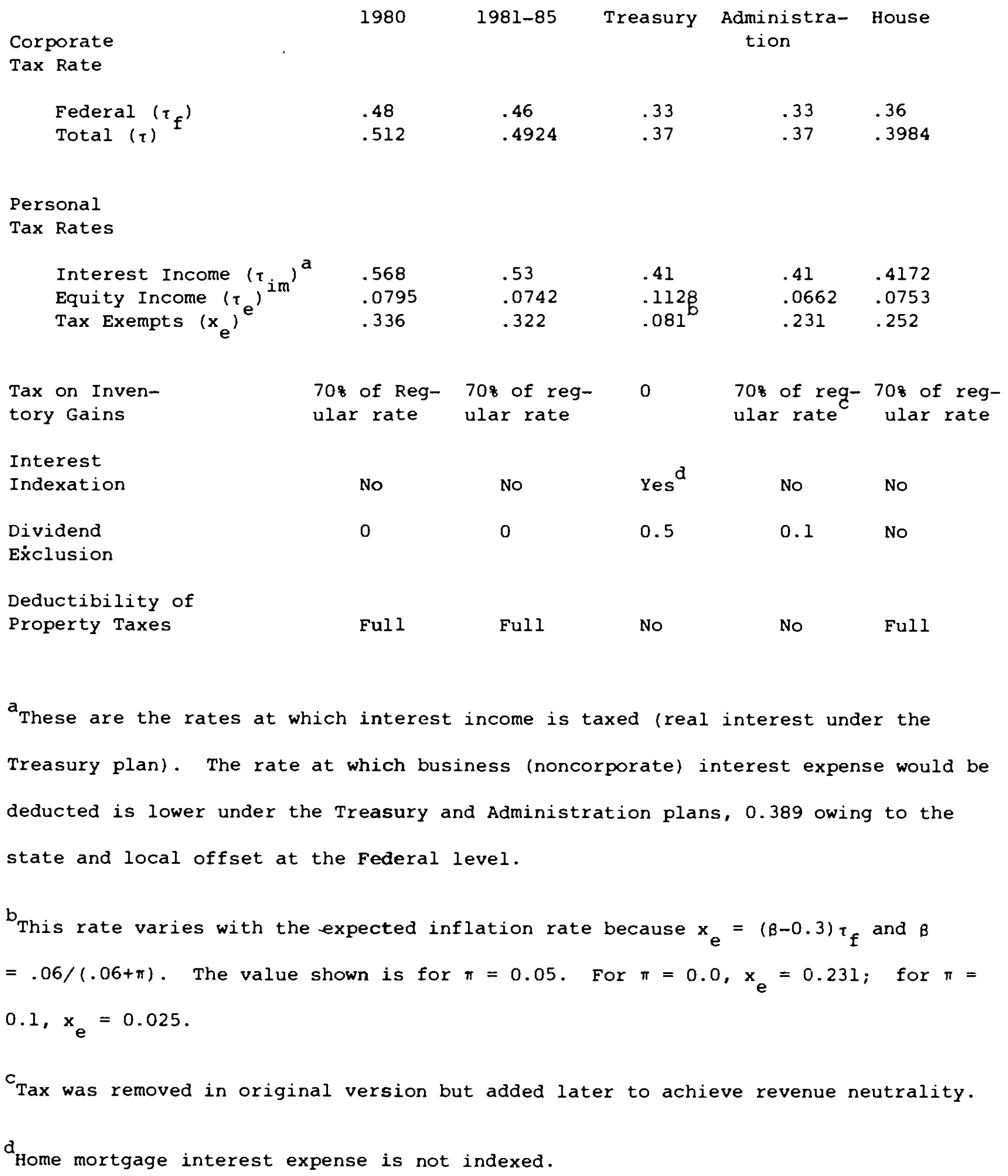


1985 Income (thousands)

$12 \frac{1}{2}-25$

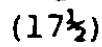

25-30

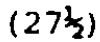

$30-50$

(35\&40)

50-100

(70)

over 100

(130)

$$
\text { Table } 4
$$

\begin{tabular}{|c|c|c|c|c|}
\hline \multicolumn{5}{|c|}{$-43-$} \\
\hline \multicolumn{5}{|c|}{ Table 4} \\
\hline & Tax Rates & Relevant to & Housing Decisions & \\
\hline $\begin{array}{l}1980 \text { Income } \\
\text { (thousands) }\end{array}$ & $\begin{array}{l}\text { State and } \\
\text { Local }\end{array}$ & Federal & $\begin{array}{c}\text { Quantity-Demanded } \\
\text { Total }\end{array}$ & $\begin{array}{c}\text { Tenure Choice } \\
\text { Total }\end{array}$ \\
\hline $\begin{array}{l}9-18 \frac{1}{2} \\
\left(12 \frac{1}{2}\right)\end{array}$ & .03 & .16 & .185 & .132 \\
\hline $\begin{array}{l}18 \frac{1}{2}-22 \frac{1}{2} \\
(20)\end{array}$ & .035 & .18 & .209 & .201 \\
\hline $\begin{array}{l}22 \frac{1}{2}-37 \frac{1}{2} \\
(30)\end{array}$ & .04 & .24 & .270 & .306 \\
\hline $\begin{array}{l}37 \frac{1}{2}-75 \\
(50)\end{array}$ & .05 & .37 & .402 & .435 \\
\hline $\begin{array}{l}\text { over } 75 \\
\left(97 \frac{1}{2}\right)\end{array}$ & .06 & .49 & .521 & .565 \\
\hline
\end{tabular}

Tax Rates Relevant to Housing Decisions

\begin{tabular}{|c|c|c|c|c|c|c|c|c|}
\hline \multicolumn{3}{|c|}{ Federal } & \multicolumn{3}{|c|}{ Quantity-Demanded } & \multicolumn{3}{|c|}{$\frac{\text { Tenure Choice }}{\text { Current Trea }}$} \\
\hline Current & $\begin{array}{l}\text { Trea } \\
\& \text { Adm }\end{array}$ & House & Current & $\begin{array}{l}\text { Trea } \\
\& \text { Adm }\end{array}$ & House & Current Trea & Adm & House \\
\hline
\end{tabular}

Tenure Choice

$\begin{array}{llllllllll}.14 & .15 & .15 & .166 & .180 & .176 & .147 & .119 & .092 & .071\end{array}$

$\begin{array}{llllllllll}.16 & .15 & .15 & .189 & .185 & .180 & .210 & .146 & .130 & .097\end{array}$

$\begin{array}{llllllllllll}.18 / .22 & .15 & .15 / .25 & .232 & .190 & .232 & .279 & .178 & .198 & .208\end{array}$

.25

$.35 \quad .364$

$.300 \quad .383$

$.402 \quad .300 \quad .300 \quad .383$

.42

.35

.455

$.410 \quad .389$

$.476 \quad .410 \quad .410 \quad .404$ 
Table 5

Private Capital stock in the U.S.

End 1983 Dollar Value

(billions)

Inventories

Corporate

Noncorporate

Equipment

Corporate

Noncorporate

Nonresidential structures

10-Year Public

utilities

15-Year Public

Utilities

Industrial

(corporate)

Commercial

(noncorporate)

Residential Structures

Corporate Rental

Noncorporate Rental

Owner-Occupied
814

769

45

1451

1183

269

18.95

20.10

6.0

4.26

4.40

3.0

1634

138

546

628

2893

40.96

$39.97-2.4$

70

553

2270
4.0

$6.86\left\{\begin{array}{ll}2.29 & 6.54 \\ 4.57 & \end{array} \begin{cases}2.18 & -4.7 \\ 4.36 & \end{cases}\right.$

7.85

7.92

0.9 
Table 6

\section{Assumed Distribution of Owner and Rental Housing Across Six Income Classes}

\begin{tabular}{|c|c|c|c|c|c|c|}
\hline \multirow{2}{*}{$\begin{array}{l}\text { Income } \\
\text { Range } \\
\text { (thousands) }\end{array}$} & \multirow{2}{*}{$\begin{array}{l}\text { Households } \\
\text { (millions) }\end{array}$} & \multirow{2}{*}{$\begin{array}{l}\text { Fraction } \\
\text { that Own }\end{array}$} & \multicolumn{2}{|c|}{8 of Income } & \multicolumn{2}{|c|}{ of Housing Stock } \\
\hline & & & of Owners & of Renters & $\begin{array}{l}\text { Owner- } \\
\text { Occupied }\end{array}$ & Rental \\
\hline \multicolumn{7}{|l|}{$\underline{1980}$} \\
\hline less than 9 & 9.6 & 0 & 0 & 11 & - & 2.7 \\
\hline $9-18 \frac{1}{2}$ & 24 & .577 & 12 & 22 & 7.6 & 4.9 \\
\hline $18 \frac{1}{2}-22 \frac{1}{2}$ & 12 & .625 & 11 & 15 & 7.1 & 3.6 \\
\hline $22 \frac{1}{2}-37 \frac{1}{2}$ & 22.4 & .707 & 34 & 34 & 24.3 & 7.9 \\
\hline $37 \frac{1}{2}-75$ & 9.6 & .813 & 28 & 15 & 23.9 & 3.6 \\
\hline \multirow[t]{2}{*}{ over 75} & 2.4 & .889 & 15 & 4 & 13.5 & 0.9 \\
\hline & 80 & & 100 & 100 & 76.4 & 23.6 \\
\hline \multicolumn{7}{|l|}{1985} \\
\hline lèss than $12 \frac{1}{2}$ & 9.6 & 0 & 0 & 11 & - & 2.6 \\
\hline $12 \frac{1}{2}-25$ & 24 & .631 & 14 & 17 & 9.4 & 4.6 \\
\hline $25-30$ & 12 & .664 & 12 & 14 & 8.0 & 3.3 \\
\hline $30-50$ & 22.4 & .703 & 33 & 33 & 23.9 & 8.0 \\
\hline $50-100$ & 9.6 & .781 & 28 & 18 & 22.2 & 4.4 \\
\hline over 100 & 2.4 & .819 & 13 & 7 & 12.1 & 1.7 \\
\hline & 80 & & 100 & 100 & 75.5 & 24.5 \\
\hline
\end{tabular}




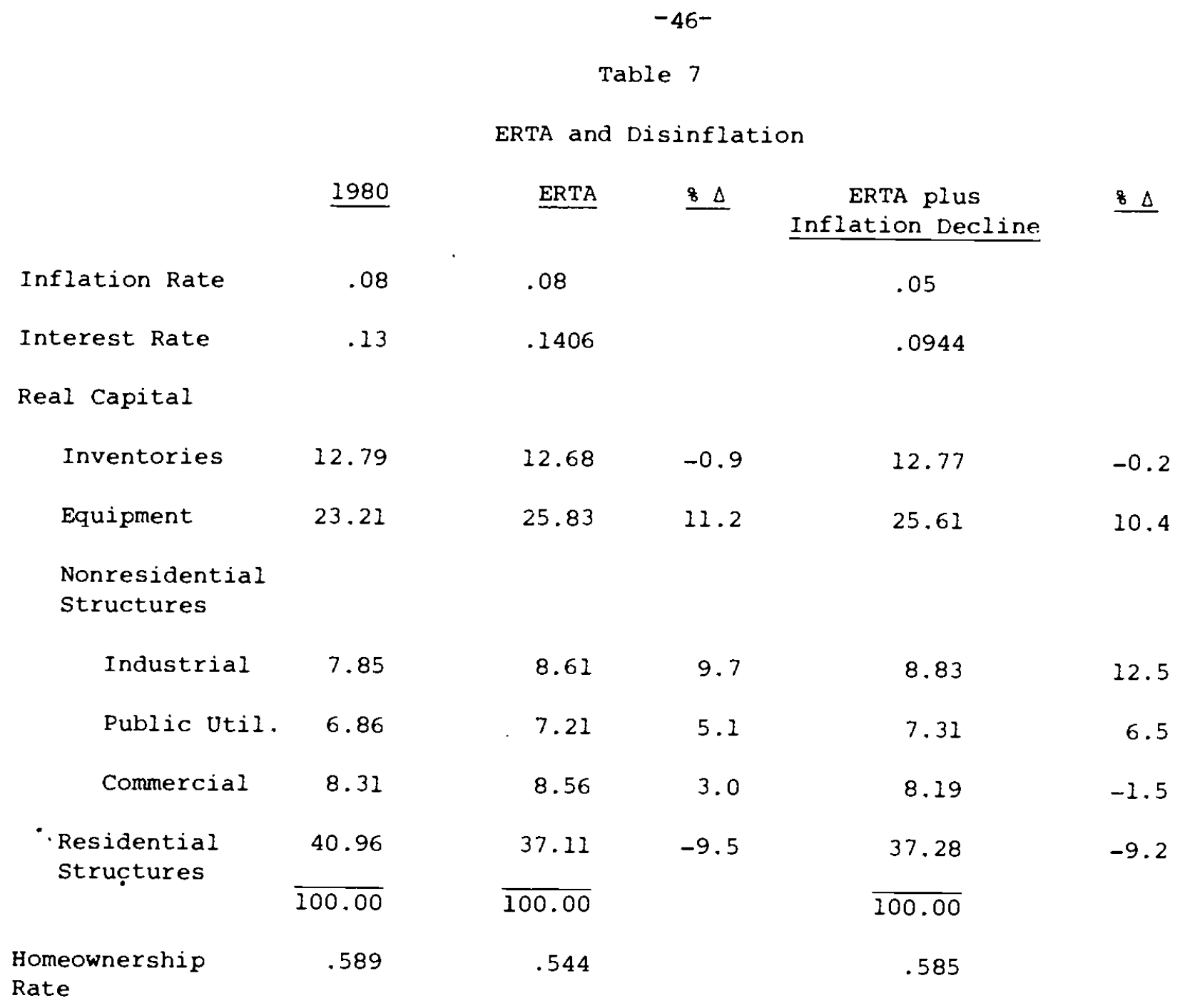

